\title{
Factors Affecting on Consumer Desire: Challenges of Mobile Phone Operators Bangladesh
}

\author{
M M Ahmmed Ruel ${ }^{1} \&$ Chung Soo Jin ${ }^{2}$ \\ ${ }^{2}$ Division of Business Administration, Wonkwang University, Iksan-si, Jeollabuk-do, South Korea \\ Correspondence: M M Ahmmed Ruel, Division of Business Administration, Wonkwang University, Iksan-si, \\ Jeollabuk-do, South Korea, Email: ruelkr@gmail.com
}

Received: August 5, 2021

Accepted: November 27, 2021

Online Published: December 15, 2021

doi:10.5539/ijbm.v17n1p78

URL: https://doi.org/10.5539/ijbm.v17n1p78

\begin{abstract}
Bangladesh, being a highly-populated area, begets a remunerative market for the telecommunication sector. Huge consumer probability attracts foreign investors provoking market competition higher entering new companies creating accrual in national GDP. To endure in the intensely competitive market, mobile telecommunication service provider companies are conscious about customer expectations and trying to compensate consumer demand offering quality services. This study elucidates the strategies of mobile phone companies to provide services to a satisfactory level, such as segmented marketing paves the way of focused marketing program which allows the companies to provide the expected services to the specific segment of consumers. This research also analyzes information collected about consumer expectations and unearths the factors affecting the volition of an operator and sketches some recommendations to the mobile phone operators.
\end{abstract}

Keywords: Bangladesh, telecommunication, consumer, market, satisfaction

\section{Introduction}

Bangladesh's telecommunications sector began in the mainstream market with the licensing of one private operator in 1989, as before the sector was monopolistic system. Government administrated organization Bangladesh Telegraph and Telephone Board (BTTB) was the only operator to provide a fixed phone service before 1989. A huge and significant change was taken place in 1990, when a numbers of operators were allowed their entrance which made a revolutionary in the telecommunication sector. For the increasing competition survive the companies took various consumer attractive measurements which made the sector one of the biggest organizations in Bangladesh. Moreover, with a vast amount of population it has a great potentiality which attracted worldwide recognized giant companies. Thus made them investment and day by day the company is being a dominant one in the market. There are actually four mobile telephone companies, offering consumer services. They are Grameenphone Ltd. popularly known as GP, Robi Axiata Ltd(Robi), Banglalink Digital Communication Ltd known as BL and Teletalk Bangladesh Ltd. Amongst them Grameenphone is the most dominant operator in this sector according to its consumer volume. Subscriber volume of four operators is given in a table here.

Table 1. Volume of subscribers of the operators (in June 2020)

\begin{tabular}{ll}
\hline Operators & Subscriber(in million) \\
\hline Grameen Phone Ltd (GP) & 74.531 \\
Robi Axiata Limited (Robi) & 47.977 \\
Banglalink Digital Communication Limited & 34.030 \\
Teletalk Bangladesh Limited & 4.757 \\
Total & 161.295 \\
\hline
\end{tabular}

Source: www.btrc.gov.bd.

BTRC, June, 2020

Providing information showing that the most dominant operator Grameenphone has a subscriber volume of 74.531 
million that has been acquired for GP's strong and countrywide network coverage, customer satisfactory service provides, less worrisome service costs and value added taxes, availability, obtainable internet services etc. The second large operator is Robi Axiata Limited (Robi) which consumer volume is 47.977 million. Banlalink Digital Communication Limited shortly known as BL which consumer volume is 34.030 million. Bangladesh government organized operator Teletalk Bangladesh Ltd has about 4.757 million. The total volume arises to 161.295 million which promulgates a dynamic sector.

\subsection{Market Share of Four Operators}

According to the information of BTRC of June, 2020, table is showing subscriber distribution or market share of four operators. In $2020 \mathrm{GP}$ is reigning near about $46 \%$ of market which is the most dominant in 2020 . The second highest market share holder is Robi. It has near about 30\% market share in 2020. Banlalink Digital Communication Limited has near about $21 \%$ of consumer of whole telecommunication market. Government demonstrated operator Teletalk has retained near about $3 \%$ of consumer of Telecommunication sector of Bangladesh.

\subsection{Literature Review}

Mobile telecommunication sector has brought a revolutionary in the context of communication system and the influence and necessity is overwhelmed. Now a day's telecommunication sector has been very competitive thus offering customer satisfactory services and offers frequently with a view to surviving in the market. So consumers can have a wide scope to choose for operators considering various factors that he needs or wants to be included in an operator or provided by. Here is occurred a problem also that one cannot easily select the best services and offers in a row of huge satisfying services and offers of six operators. According to (Hemmati et al., 2012), the choice of a mobile operator in a highly competitive market is a difficult dilemma for a customer who has to select the most appropriate contact operator. In the context of Bangladesh with a massive population this sector has flourished overwhelming the whole business industry and yet has a lot of potentialities to retain require serious research and market analysis. Though some researchers have been lunched some research work to draw the figure how factors affecting consumer volitions towards selecting an operator. In Bangladesh perspective research, (Hasan et al., 2013) suggested to concentrate on the lowest possible price, good network coverage and quicker internet access in order to attract and maintain clients.

A research conducted by Shah in India (2012) found that main factors that were central to the telecom industry's accrual were massive markets, advanced technology, lower tariffs and low handset costs. The author observed that telecommunication has become an unavoidable part of the life of people on one side; while on the other side the operators are continuously increasing competition by discovering new pricing strategy, lucrative schemes, valueadded services, etc. Priority is given to quality of operation, brand identity, service charge and quality of the network, respectively when to select an operator. Switching cost is defined as the cost that incurs when a consumer change one service provider to another (Porter, 1998). Switching costs are also described as the expenditure of time, money and effort which made it difficult to switch in the view of the customer. It is the consumer's estimate of the personal loss or sacrifice associated with the customer moving to another service provider in time, energy and money (Hellier, Rickard, Carr, \& Geursen, 2002).

So it is something more worrisome to switch from one operator to another than that of selecting the perfect operator. With a view to cope with these problem operators should aware of providing the best service that wouldn't inspire consumer to switch as it may have a great effect on operator's performance. If the service level that the consumers interpret as good or negative, then it directly affects their corporate identity (Keller, 1993).

Available communicative network and price are the most influencing factor that can motivate consumers' choice. Agility is regarded as important in solving customer problems and short message service, while mobile entertainment is of moderate importance. Study also showed less use of technology and call waiting, call forwarding is considered not relevant (Paulrajan et al., 2011). A research work in Pakistan by Khan (2010) gave emphasis on providing service timely, accurately and reliably.

\subsection{Objectives}

In technology based era mobile telecommunication sector has become indispensable in our life in a country which has been declared as digital Bangladesh. Government has taken various steps to develop this sector sustainable, regarding this motto monopolistic sector now allowed six operators to provide service to public thus make the sector consumer satisfying, mass involvement reducing user cost by intensifying competition amongst operator which are always making innovative strategies, cost management, new technologies, wide range strong network to endure in the market. So now researches needed to reveal factors shape the market, factors affecting consumer choices, reasons behind switching from one operator to another operator etc. The purpose of this study is to find 
out the circumstances mentioned, and also give the operators some clear recommendations.

The objectives are as follows:

- To find out contentions behind the consumers changing of operators

- To look for materials which shape consumer volition

- Analyzing the profiles of the consumers

- To give suggestions to some specific operators

\section{Methodology}

Here is showed how the research work is conducted to determine the consumers' expectations from telecommunication service provider operators of Bangladesh and how they affect volitions by discussing with peoples, measuring factor instrumentation, sampling procedure, data collection and data processing. The sample unit would be single subscriber as the motto of the study is to determine the thoughts of consumers' about services provided by different operators and how thoughts demonstrate subscribers' choices towards different service provider operators.

Samples were selected randomly for the procedure of the research and separated in quota such as in this study there was selected seven types of quota as; Govt. jobholder, Private jobholder, Businessman, Student, Homemaker, Jobless and Retired person. Determined sample quota number was seven and volume of sample was 700 .

Selected questionnaire was included materials used is various study related to this research and was selected from interviews of consumers. Kim et al. (2004) studied on Korean mobile communication sector. In his study he proclaims that, customer satisfaction is strongly linked to call quality, value-added services and customer support, and these factors are very important when choosing a telecommunications operator. Quinn et al. (1987) conducted a study in which convenience, amusement and timeliness were identified as dominant factors. Girish and Neeraj (2007) identified customer service, call rates, promotion and availability as the most important import factors.

Data for analysis was collected from the megacity of Dhaka. For factor analysis to detect factors affecting customers' choice to select an operator, used SPSS version. Some analyses were conducted in description manner.

\section{An Overview on Telecommunication Service Provider Operators in Bangladesh}

Bangladesh telecommunications industry started its journey in 1989 with the approval of license of private operator Bangladesh Telecom Ltd as the first cellular phone to provide service. In 1997 a breakthrough in telecom sector been took place as that year three operators were given license. Grameenphone, Aktel and Sheba telecom were awarded license in the same year but Grameenphone commonly known as GP retained the first place in the short next time. For being a very competitive market the industry is getting huge growth dates update. The factors contributing to this growth are: limited performance of fixed-line operators, substantial foreign direct investment (FDI) and lower prices driven by increased competition and economies of scale (Lane et al., 2007). An overview of the different operators is provided below;

\subsection{Telenor Bangladesh Ltd (Grameenphone)}

Telenor Bangladesh Ltd, locally known as grameenphone, popularly named gp started its operations to provide services privately on March 26, 1997, having share owned $62 \%$ by Telenor Telecommunication Operator of Norway and $38 \%$ by Grameen Telecom. This is the largest operators of the industry having a volume of about 56.285 million acquiring about $43 \%$ of whole industry. There were about 5200 BTS (base tower stations) at the end of 2008. The tower range is $5-7 \mathrm{~km}$. Grameenphone aims to cost effective and quality services to the consumer. They have the strongest network throughout the country. Technically supported by Hawaii and Erickson, it always tries to give service in due time and at a satisfactory level. GP has though about 56.285 million; it has altogether about 100 million of subscribers. It has GSM (global system of mobile communication) and $3 \mathrm{G}$ network services.

\subsection{Robi Axiata Ltd}

Aktel Axiata Group Berhad, Malaysia and NTT DOCOMO INC, Japan is joint ventures were founded in 1997. On 28 March 2010, it was rebranded as "Robi-submitted," a Bengali word meaning "sun-submitted" and from then on the company is known as "Robi-Axiata Limited" (Robi. 2013). The year of 2020 Robi is the second position in Telecommunication sector in Bangladesh.

\subsection{Banglalink Digital Communication Ltd}

Formerly known as Sheba Telecom Pvt Ltd has been providing GSM services since 1998, when Orascom Telecom purchased $100 \%$ of Sheba Telecom's share in 2004, naming the operator as Banglalink. This operator started 
operations in February 2005 with a slogan 'Making it Difference.' They have been providing quality service to consumers according to their slogan achieving second position with a volume of 34.030 million subscribers in 2020 which is about $21 \%$ of the telecommunication industry of Bangladesh. In August 2006, Banglalink becomes the first operator to provide free incoming BTTB calls for both postpaid and prepaid connections. According to a study launched in 2013, it has over 700 customer care points and has invested about 6,324 cores BDT. Strong network over the country having tower range of 5-9 km which in times is $13-15 \mathrm{~km}$, it is providing services to the customers technically supported by Nokia-Siemeans Network and Hawaii.

\subsection{Pacific Bangladesh Telecom Ltd}

Citycell, Bangladesh's number one mobile telecommunications service is the country's only CDMA network operator. In 1989, Bangladesh Telecom Limited (BTL) was granted a license to operate in cellular, paging and other wireless communications networks. In 1990, BTL and Hutchison Telecommunications (Bangladesh) Limited entered into a joint venture which was incorporated as Hutchison Bangladesh Telecom Limited (HBTL). In 1993, HBTL was the first cellular operator in South Asia started its commercial operation in Dhaka. In the last part of that year Pacific motors bought $50 \%$ of BTL and as a result by 1996 HBTL was renamed as Pacific Bangladesh Telecom Limited (PBTL) which started trading under the brand name 'Citycell Digital' for the marketing of its products. PBTL was converted into a Public Limited Company with effect from 28 March 2008. The shares have now again been redistributed between three partners: Pacific Motors Limited (31.43\%), Far East Telecom Limited (23.57\%), and SingTel Asia Pacific Investments Pvt. Ltd (45\% of the population). Technologically supported by Hawaii, Ericsson, Motorola and its tower range is $5-6 \mathrm{~km}$ but in case they cover about $9 \mathrm{~km}$. It is the first private operator but because of their some weakness in strategy they have lost of about 1,35,000 subscribers in the last year. But now a days Citycell markt share are not significant in Telecommunication sector of Bangladesh.

\subsection{Teletalk Bangladesh Ltd}

Single operator governed by Government of Peoples' Republic of Bangladesh. Started its operations incorporated as GSM based state owned telecommunication operator and it was the demonstrator in using $3 \mathrm{G}$ network in Bangladesh. The telecommunication sector is facing severe competition in the market. So they have to apply unique and customer demanded services according to their choices to lead the market. Though it is demonstrated by Government, it couldn't acquire predicted success. Teletalk has a volume of subscribers of about 4.757 million in June, 2020 which is about 3\% of the industry. Its position in the market is fifth. So it has enough scope to develop their business strategy, even they can use the emotional soft of being a state governed operator as their business strategy.

\subsection{Airtel Bangladesh Ltd}

Airtel Bangladesh Ltd popularly known as Airtel is GSM based cellular operator enterer in the telecom market. It started operation to provide services on May 10, 2007. Airtel International LLC paid 50 million USD in December 2005 for BTRC to acquire a GSM license. Airtel has been providing 3G network. But now a days Airtel markt share are not significant in Telecommunication sector of Bangladesh.

\section{Recognition}

Recognition is presented here through statistical analysis. The respondent's first demographic profile is analyzed, followed by factor analysis to classify factors that are responsible for influencing the choice of consumers, the latter part assesses value added services (VAS). Demographic profile of the Respondents. 
Table 2. Demographic profile

\begin{tabular}{lll}
\hline & Respondents & Percentage \\
\hline Gender & & \\
Male & 455 & $65 \%$ \\
Female & 245 & $35 \%$ \\
Total & 700 & $100 \%$ \\
Profession & & \\
Govt. job holder & 140 & $20 \%$ \\
Private job holder & 70 & $10 \%$ \\
Businessman & 140 & $20 \%$ \\
Student & 140 & $20 \%$ \\
Homemaker & 70 & $10 \%$ \\
Retired person & 70 & $10 \%$ \\
Jobless & 70 & $10 \%$ \\
Total & 700 & $100 \%$ \\
\hline
\end{tabular}

Total frequencies were surveyed, $65 \%$ of them were male and $35 \%$ were female. Data also analyzed based on respondents' individual occupations. Amongst 700 respondents, govt. job holder is 140, private job holder 70 , businessman 140 , student 140 , homemaker 70 , retired person 70 , jobless 70 . For each occupation, this varying number of respondents explains the disparity between the number of male and female respondents.

\subsection{Factor Analysis}

Factors affecting consumer volitions

Importance level:

$1=$ Not important at all

$2=$ Less important

$3=$ Important

$4=$ Very important

$5=$ Most important

Table 3. Powerful network coverage:

\begin{tabular}{ll}
\hline Range of importance & Frequencies \\
\hline 1 & 25 \\
2 & 100 \\
3 & 125 \\
4 & 200 \\
5 & 250 \\
\hline
\end{tabular}

Table 4. Low call rate

\begin{tabular}{ll}
\hline Importance range & Frequency \\
\hline 1 & 25 \\
2 & 75 \\
3 & 100 \\
4 & 200 \\
5 & 300 \\
\hline
\end{tabular}


Table 5. Low connection price

\begin{tabular}{ll}
\hline Importance range & Frequency \\
\hline 1 & 50 \\
2 & 100 \\
3 & 200 \\
4 & 200 \\
5 & 150 \\
\hline
\end{tabular}

Table 6. Strong internet facilities

\begin{tabular}{ll}
\hline Importance range & Frequency \\
\hline 1 & 50 \\
2 & 95 \\
3 & 150 \\
4 & 225 \\
5 & 180 \\
\hline
\end{tabular}

Table 7. Customer service quality

\begin{tabular}{ll}
\hline Importance range & Frequency \\
\hline 1 & 50 \\
2 & 100 \\
3 & 100 \\
4 & 300 \\
5 & 150 \\
\hline
\end{tabular}

Table 8. Simple call rate policy

\begin{tabular}{ll}
\hline Importance range & Frequency \\
\hline 1 & 50 \\
2 & 100 \\
3 & 200 \\
4 & 200 \\
5 & 150 \\
\hline
\end{tabular}

Table 9. Discounts

\begin{tabular}{ll}
\hline Importance range & Frequency \\
\hline 1 & 55 \\
2 & 100 \\
3 & 150 \\
4 & 200 \\
5 & 195 \\
\hline
\end{tabular}


Table 10. Offers

\begin{tabular}{ll}
\hline Importance range & Frequency \\
\hline 1 & 50 \\
2 & 100 \\
3 & 150 \\
4 & 200 \\
5 & 200 \\
\hline
\end{tabular}

Table 11. Free internet access

\begin{tabular}{ll}
\hline Importance level & Frequency \\
\hline 1 & 55 \\
2 & 95 \\
3 & 200 \\
4 & 250 \\
5 & 100 \\
\hline
\end{tabular}

Table 12. Free access into social media

\begin{tabular}{ll}
\hline Importance level & Frequency \\
\hline 1 & 20 \\
2 & 75 \\
3 & 175 \\
4 & 250 \\
5 & 180 \\
\hline
\end{tabular}

Table 13. Brand image

\begin{tabular}{ll}
\hline Importance level & Frequency \\
\hline 1 & 40 \\
2 & 85 \\
3 & 175 \\
4 & 225 \\
5 & 175 \\
\hline
\end{tabular}

Table 14. Friends and family influences

\begin{tabular}{ll}
\hline Importance level & Frequency \\
\hline 1 & 25 \\
2 & 75 \\
3 & 100 \\
4 & 300 \\
5 & 200 \\
\hline
\end{tabular}


Table 15. Welcome tunes

\begin{tabular}{ll}
\hline Importance level & Frequency \\
\hline 1 & 275 \\
2 & 200 \\
3 & 150 \\
4 & 50 \\
5 & 25 \\
\hline
\end{tabular}

Table 16. SMS

\begin{tabular}{ll}
\hline Importance level & Frequency \\
\hline 1 & 30 \\
2 & 100 \\
3 & 175 \\
4 & 195 \\
5 & 200 \\
\hline
\end{tabular}

Table 17. Jokes

\begin{tabular}{ll}
\hline Importance level & Frequency \\
\hline 1 & 250 \\
2 & 250 \\
3 & 150 \\
4 & 50 \\
5 & 00 \\
\hline
\end{tabular}

Table 18. Credit transfer

\begin{tabular}{ll}
\hline Importance level & Frequency \\
\hline 1 & 75 \\
2 & 150 \\
3 & 200 \\
4 & 175 \\
5 & 100 \\
\hline
\end{tabular}

Table 19. Occasional gifts

\begin{tabular}{ll}
\hline Importance level & Frequency \\
\hline 1 & 75 \\
2 & 75 \\
3 & 200 \\
4 & 200 \\
5 & 150 \\
\hline
\end{tabular}


Table 20. Ringtones

\begin{tabular}{ll}
\hline Importance level & Frequency \\
\hline 1 & 300 \\
2 & 200 \\
3 & 150 \\
4 & 50 \\
5 & 00 \\
\hline
\end{tabular}

\subsection{Impact of Value Added Services}

Respondents were asked about the importance of value added services based on which we can determine the impact of value added services in the context of customer volitions provided by telecommunication service provider operators of Bangladesh.

Rating Scale: $1=$ not important at all, $2=$ less important, $3=$ important, $4=$ very important.

Table 21. Internet facilities

\begin{tabular}{ll}
\hline Factor Importance & Frequency \\
\hline 1 & $5 \%$ \\
2 & $10 \%$ \\
3 & $30 \%$ \\
4 & $55 \%$ \\
\hline
\end{tabular}

Bangladesh was declared as Digital Bangladesh proceeding to a project 'vision 2021'. With a view to achieving the milestone she has given more importance on ICT sector developing internet facility with the new acquaintance with $3 \mathrm{G}$ network.

\section{Recommendations}

Firstly, for every operator, network availability is the most concerned issue. So operators should try to spread the network service all over the country. For instance, we can see the most powerful network service is given by the Grameenphone and this company has about half of the active connections.

Secondly, Call rate is another most effective factor to be succeeded in the market. Grameenphone has the highest call rate in consideration of six operators. They should lessen the call rate not only for gp to gp users but also for gp to other operators.

Thirdly, prepaid customers would give priority than the postpaid customers as the prepaid customers are the most consumers.

Fourthly, Companies should be aware of the customer services regarding customer benefits.

Fifthly, Value added services are mostly found not very useful to the customers because of their handsets or connections. Operators should take attempt in increasing usefulness of this value added services.

Sixthly, Customer care service should be more fruitful to the customers. Now most of the people are much more aware of the quality service.

Seventhly, Easy load and flexi load validity should be increased. It should make available for customers to find easy load or flexi load.

Eighthly, Charge should be reduced when damaged or lost SIMs is activated again.

Ninthly, for any organization customer satisfaction is the key to survive or be succeeded. From study we see, in this case they are not enough satisfactory. So they should recruit devoted manpower and give them proper training to develop customer service. 


\section{Conclusion}

Telecommunication industry in Bangladesh is becoming influential both for the social and economic sector. Bangladesh is now known as digital Bangladesh. The motto of digital Bangladesh is, people of this country would be come under the internet connection which is being fulfilled by the six operators. They also have a great influence over the national economy. They pay for revenue, make employment for people etc. Though, this sector has some obstacles to overcome but also have some prospects. They should all work together to achieve the maximum profit with serving the best service to the customer.

\section{References}

Girish, T., \& Neeraj, K. (2007). Customer Perception Towards MTSPs: An Analytical Study. The IUP Journal of Service Marketing, 5(3), 34-52.

Hasan, K. M., Yeasmin, A., \& Dey, P. (2013). Factors Influencing to Bangladeshi Consumers: Mobile Phone Operators Choice and Change Behavior. Journal of Economics and Sustainable Development, 4(2).

Hellier, P. K., Geursen, G. M., Carr, R. A., \& Rickard, J. A. (2003). Customer repurchase intention: a general structural equation model. European Journal of Marketing, 37(11), 1762-1800. https://doi.org/10.1108/03090560310495456

Hemmati, S., Shapouri, F., \& Keramati, A. (2012). Evaluating the Iran Mobile Communication Operators by Analytical Network Process (ANP). Telecommunications System \& Management, 2(1).

Keller, K. L. (1993). Conceptualizing, measuring, and managing customer-based brand equity. Journal of Marketing, 57(1), 1-22.

Khan, A. M. (2010). An Empirical Assessment of Service Quality of Cellular Mobile Telephone Operators in Pakistan. Asian Social Science, 6(10).

Kim, M. K., Park, M. C., \& Jeong, D. H. (2004). The Effect of customer Satisfaction and switching Barrier on customer loyalty in Korean mobile Telecom Services. Telecommunication Policy, 28(2), 145-149.

Lane, B., Sweet, S., Lewin, D., Sephton, J., \& Petini, O. (2007). The Economic and Social Benefits of Mobile Services in Bangladesh: A case study for the GSM Association.

Paulrajan, R., \& Rajkumar, H. (2011). Service Quality and Customers Preference of Cellular Mobile telecommunication service providers. Journal of Technology Management \& Innovation, 6(1).

Robi. (2013). About Robi Bangladesh. Retrieved from https://www.robi.com.bd/en/personal/about-robi

Shah, C. (2012). Consumer Preferences for Mobile telecommunication service providers: An Empirical Study in Bardoli. International Journal of Marketing and Technology, 2(8). Retrieved from https://books.google.com.bd/books?id

\section{Copyrights}

Copyright for this article is retained by the author(s), with first publication rights granted to the journal.

This is an open-access article distributed under the terms and conditions of the Creative Commons Attribution license (http://creativecommons.org/licenses/by/4.0/). 